\title{
EXAMINATION OF IBN BATUTA TRAVEL BOOK IN ACCORDANCE WITH 7th CLASS SOCIAL STUDIES OUTCOMES
}

\author{
Zeynep Öncü ${ }^{1}$ \\ Nusret Koca ${ }^{2}$, \\ Mehmet Tamer Kaya ${ }^{2 i}$ \\ ${ }^{1} \mathrm{MSc}$, Faculty of Education, \\ Afyon Kocatepe University, \\ Afyonkarahisar, Turkey \\ ${ }^{2}$ Prof., Faculty of Education, \\ Afyon Kocatepe University, \\ Afyonkarahisar, Turkey \\ ${ }^{2}$ Dr., Faculty of Education, \\ Afyon Kocatepe University, \\ Afyonkarahisar, Turkey
}

\begin{abstract}
:
The aim of this research is to examine Ibn Batuta's Travel Book in line with the 7th grade acquisitions in the social studies curriculum. In the research, the 2-volume work of the author was examined by using the document analysis method as a data collection tool; In addition, in the direction of the findings obtained, the category-code and direct quotations were examined in detail with content analysis. In the research, 5 categories and 11 codes related to the 7 th grade 10 achievement were created. The category-code and content created in line with the findings obtained in the research are supported by direct quotations and given with page and volume numbers. It has been determined that the most related acquisitions in the research are in the learning fields of Individual and Society, People, Places and Environments, Science, Technology and Society, Production, Distribution and Consumption; the least associated acquisitions are included in the Cultural Heritage and Global Connections learning areas; It has been determined that the acquisitions that are not associated at all are included in the Active Citizenship learning area.
\end{abstract}

Keywords: Seyahatname, Ibn Batuta, social studies

\section{Introduction}

Travelogues are first-hand sources that describe the socio-cultural values, historical and geographical places of the geographies where the author was during his travels. Many

i Correspondence: email mtkaya@aku.edu.tr, tamer kaya 07@hotmail.com 
works have been given in our country and around the world in line with the subject and the geographies discussed.We can list the travel books that can be used in teaching social studies lessons from these works as follows: Ibn-i Batuta's Tuhfeü'n-Nüzzar fi Garaibi'lEmsal work, known as Rihle, gives important information about 16th century Islamic societies, China and Sumatra. In Turkish literature, the most important names are Evliya Çelebi, Ahmet Haşim; Frankurt Travel Book, Falih Rıfkı Atay, our Mediterranean, Danube Coasts, Passenger Book, Reşat Nuri Güntekin, Anatolian Notes, 28 Çelebi Mehmet Efendi's "French Sefaretnamesi", Marco Polo, Marco Polo Travel Book, Ibn-i Fazn, Ibn-i Phasen travel book, Seydî Ali Reis, Miratü'l Memalik, Kâtip Çelebi's Cihannüma, Cenap Şehabettin's On the Hajj Road, European Letters and Afak-1 Iraq, Haldun Taner, Dream Roads, İlber Ortaylı's, Ottomans in Three Continents, Yavuz Bülent Bakiler, Turkistan Turkistan and Kosovo from Skopje, İsmail Habib Sevük, Writings from the Homeland (Öztürk, Otluoğlu, and Coşkun, 2014: 134; Maden, 2008: 149-155). In the social studies course curriculum prepared in line with the constructivist approach, "Social Studies course should be supported with literary products by making use of genres such as legends, epics, fairy tales, proverbs, folk tales, folk songs and poems. Students should be encouraged to read literary products such as novels, historical novels, stories, memoirs, travel writings and anecdotes that will make them love the subjects. In addition, appropriate acquisitions should be supported with traditional or modern art products such as painting, music, miniature, engraving, calligraphy, sculpture, architecture, theater, cinema" (MEB, 2018), and it is emphasized that various literary products and materials should be used in the social studies course. In this direction, it can be said that travel books can be used in teaching social studies.

Today, different definitions of travelogues, which contain important information in terms of adaptation of people living in the past to historical and geographical conditions and shaping their geography, are given. In Arabic literature, the word "rihle" is mostly used in the sense of "travel" and "journeyname" (Yazicl, 2009: 9). Travel book with its definition in the Turkish Language Institution (TDK) (2019): While defined as a work in which an author describes his knowledge and impressions from the places he has visited, Asiltürk (2009: 912) defines it as the work in which the traveler tells his impressions about the places he has visited in a narrow or wide geography.

By examining these works, it can be said that they will serve to gain various values and skills in line with the psychological and sociological development of students. It is thought that the use of literary products and written materials together with different methods and techniques will serve the purposes in the social studies program today, where skill and value teaching gains importance. Öztürk and Otluoğlu (2002) have come to the conclusion that the use of oral and written literary products in the course contributes to the child in terms of affective behavior characteristics such as the student's desire, feeling more comfortable, adding to his personality, understanding / telling, remembering, visualizing, connecting with what he has learned, and cognitive competencies. In studies on the use of travelogues in social studies education (Yakar, 2013; Ata, 2013; Kaya and Ekici, 2015; Çelik, 2016; Oruç and Aygün, 2018; Çelik, 2019; 
Baştuğ, 2019) stated that travel books deal with the subjects that can be used in social studies education. In their study, Dündar and Baysan (2017: 299) emphasized that the oral and written cultural elements transferred from generation to generation, constitute the basic elements of cultural heritage, and concluded that the use of travel books in education would be beneficial for the interest and motivation of students.

One of the works that can be used in teaching the aims and achievements planned to be given in the social studies program is the Travel Book of Ibn Batuta. Ibn Batuta, who left Tanca for pilgrimage at the age of 22, and with the influence of his curious personality, traveled to different cities in three continents, Africa, Asia and Europe, is called the greatest Muslim traveler of the period. it is known that the traveler known as Ebu Abdullah Muhammed b. Abdullah B. Muhammed B. İbrahim Levati Tanci was born in the city of Tangier, Morocco, on February 17th (703/25) on February 1304. The information that his family is a member of the berber Levate tribe who migrated here from Berka is also mentioned in his work "Rihle". It is known that he died in 1325 (725) and 770/1368 while he was a Tâmesnâ judge (Aykut, 2018; Çevik, 2015). Although it is known that the traveler spent his youth years traveling, we learn the most accurate and valid information about Ibn Batuta from Ibn Batuta's narration and Ibn Juzeyy's pen. The disappearance of the notes he took during his travel and the fact that the places he did not travel were included in his travel book in line with the information he obtained from his surroundings, caused criticism in terms of the fact that the work contains correct and valid information. "However, I will tell you the events that I have seen with my own eyes, witnessed personally and happened next to me. God knows that my words are true; that's enough, as a witness. It has spread to regions close to India such as Yemen, Khorasan and Faris" (Aykut, 2018: 665: 2). He repeats the words of Ibn Juzeyy and Ibn Batuta in response to the doubts that may arise about the work. It is thought that the trust and interest shown in the regions he travels to may be evidence of the decrease in doubts about the traveler.

In this research, it is aimed to examine Ibn Batuta's Travel Book in line with the 7th grade achievements in the social studies curriculum. The reason why Ibn Batuta's Travel Book was chosen was that it was shown as one of the most important travelers of the Middle Ages and it was decided to examine the topics he dealt with, since the geographies he traveled to include information that can be used in social studies achievement, value and skill education. Travel books are among the resources that should be used in the social studies curriculum. It is thought that Ibn Batuta's Travel Book is one of the important sources in terms of perceiving change and continuity among these sources.

\section{Material and Methods}

\subsection{Model of the Research}

In the research, document analysis, which is one of the qualitative research methods used in research in the field of social sciences, was used. In this study, document analysis which is a qualitative research method was used to determine the status of the 7th grade 
acquisitions in the social studies curriculum of the book titled İbn Batuta Seyahatname, which was published in 2 volumes in 2018 with the translation of A. Sait Aykut used.

Document analysis can be defined as a data collection tool by using various written and visual materials in cases where past events and phenomena cannot be reached through experimentation, interview and observation. Yıldırım and Şimşek (2016: 189) define document review as "analysis of written materials containing information about the case or cases aimed to be investigated".

\subsection{Working Group}

The study group of our research consists of the Yapı Kredi Publications (2018) Travel Book of Ibn Batuta, which was prepared in 60 chapters, with a total of 1104 pages and two volumes, and the 7th grade achievements in the 2018 Social Studies course curriculum.

\subsection{Analysis of Data}

In content analysis, the object is the materials that express the communication in hand, and its purpose is to make inferences from the materials at hand and to see what the dimensions of social reality are in the communication contained in the materials. This is possible with various inferences from the available data (Mayring \& June, 2000; cited in Demir, 2017: 346). While Bilgin (2017) briefly defines content analysis as "a set of methodological tools and techniques applied to a wide variety of discourses...", Tavşanc1l and Arslan (2001: 19) defines content analysis as the process of systematically analyzing written and oral materials and quantifying what people say and write by coding them according to clear instructions. Based on the definitions made, it can be said that content analysis is a process of in-depth examination of the findings.

In the research, the Travel Book of Ibn Batuta, which was published in 2 volumes, was examined in detail in line with the achievements in the 7 th grade social studies curriculum. In line with the findings obtained, a category-code was created. The findings related to the categories and codes created were supported with the relevant achievements. The direct quotations obtained are supported by presenting figures and tables together with page numbers and volume numbers.

\section{Findings and Comments}

In this part of the research, the category-code and direct quotations obtained in line with the achievements of Ibn Batuta's Travel Book in the 7th grade social studies curriculum are included. 5 categories and 11 codes were created for 10 acquisitions in the 7 th grade social studies curriculum. The findings were supported by direct quotations.

The achievements in Ibn Batuta's Travel Book are given in Table 1. 
Table 1: 7th Grade Social Studies Course Outcomes In The Travel Book of Ibn Batuta Questions their own attitudes and behaviors by analyzing attitudes and behaviors that affect communication.

Discusses the role of media in social change and interaction.

Explains the process of the emergence of the Ottoman Empire as a political power and the factors affecting this process.

Through case studies, makes inferences about the factors affecting the settlement from the past to the present.

Interprets the demographic characteristics of Turkey based on the factors affecting the distribution of the population in Turkey.

It examines change and continuity in the protection, dissemination and transfer of knowledge.

Discusses the contributions of the scholars who grew up in the Turkish-Islamic civilization to the scientific development process.

It gives examples of the work of institutions and non-governmental organizations and their roles in social life.

Recognizes the institutions that played a role in providing profession and professional ethics in Turks throughout history.

Question the stereotype views of various cultures.

As can be seen in Table 1, Ibn Batuta's travel book is directly associated with 10 acquisitions in the 7th grade social studies curriculum. It has been determined that the acquisitions in the program are in the learning areas of Individual Society, Cultural Heritage, People, Places and Environments, Science, Technology and Society, Production, Distribution and Consumption, Global Connections but there are no findings related to the acquisitions in the field of Active Citizenship learning.

The category-code and contents obtained in line with the 7th grade social studies course achievements in Ibn Batuta's travel book are given in Table 2.

Table 2: Category-Code and Contents of the Seventh

Grade Outcomes in the Social Studies Curriculum

\begin{tabular}{|l|l|l|}
\hline \multicolumn{2}{|c|}{ Category } & \multicolumn{1}{c|}{ Code } \\
\hline \multicolumn{1}{|c|}{$\begin{array}{c}\text { Social Relations Communication } \\
\text { from past till now }\end{array}$} & \multicolumn{1}{c|}{$\begin{array}{c}\text { Attitudes, Behaviours and } \\
\text { Communication Means }\end{array}$} \\
\hline \multirow{3}{*}{ Cultural Elements } & Period of Principalities & Orhan Khan \\
\cline { 2 - 3 } & Different Cultures & Hospitality, Indian country \\
\hline \multirow{3}{*}{$\begin{array}{l}\text { Science, Technology } \\
\text { and Sciety }\end{array}$} & Landforms & River Asi, Gölhisar \\
\cline { 2 - 3 } & Transportation-Economy & City of Aleppo, Kastamonu \\
\cline { 2 - 3 } & Agriculture & Orchard-Garden \\
\hline \multirow{2}{*}{$\begin{array}{l}\text { Non-govermental } \\
\text { Organizations }\end{array}$} & Protection of knowledge & Pyramids \\
\cline { 2 - 3 } & Science and Culture Centers & Bukhara, Samarkand, Baghdad, Kûfe \\
\cline { 2 - 3 } & Turkish-Islamic Scholars & Harezmi \\
\hline
\end{tabular}


As can be seen in Table 2, a total of 5 categories, 11 codes and contents created in line with the findings related to the 7 th grade achievements of the social studies course in Ibn Batuta's Travel Book are included.

The Category-Code and Contents of the Seventh Grade (7.1.1) Questioning Their Own Attitudes and Behaviors by Analyzing Attitudes and Behaviors Affecting Communication are given in Figure 1

Figure 1: Category-Code and Contents Related to Social Studies 7.1.1 Gains

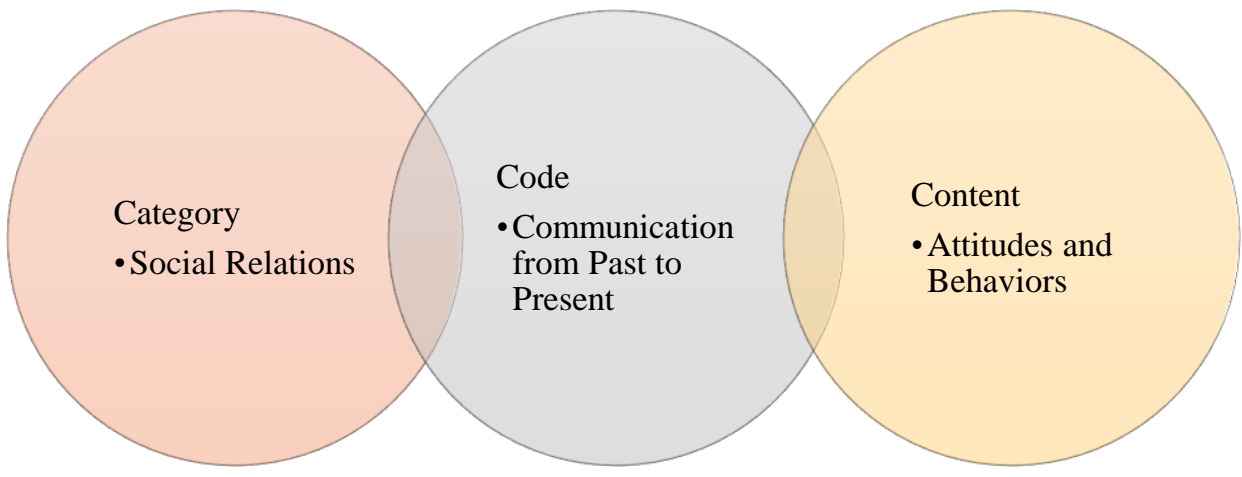

In Figure 1, direct quotations from the "Attitudes and Behaviors" content related to the "Communication from Past to Present" code in the "Social Relations" category associated with the 7.1.1 achievement obtained in Ibn Batuta's Travel Book are as follows:

"Hıdır Bek, son of Aydınoğlu Muhammed, I had seen him before with his father in Birki. I met him again out of town. He didn't like me for greeting him on horseback. This behavior caused him to leave me without a gift. According to their custom, the passenger should dismount to greet. Then the gentlemen get off their horses and salute. This move is highly appreciated by them." (Aykut, 2018, s.425, C.1).

The Category-Code and Contents of the Seventh Grade (7.1.3) Discusses the Role of the Media in Social Change and Interaction are given in Figure 2:

Figure 2: Category-Code and Contents Related to Social Studies 7.1.3 Gains

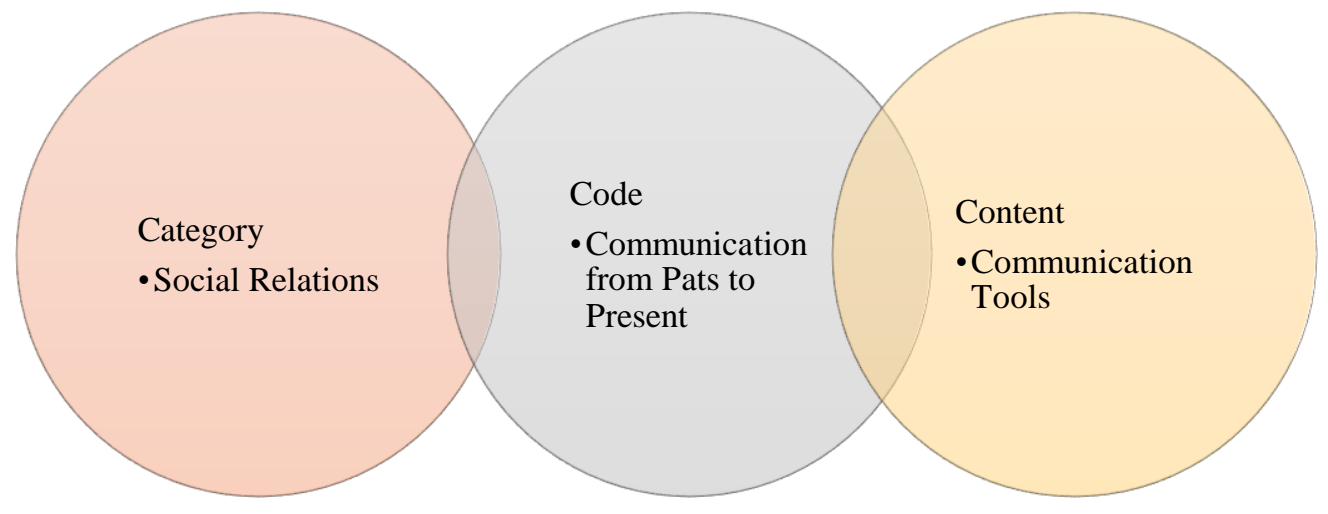


In Figure 2, direct quotations from the "Communication Tools" content related to the "Communication from Past to Present" code in the "Social Relations" category associated with the 7.1.3 achievement obtained in Ibn Batuta's Travel Book are as follows:

"There is a fifty-day road between Sint and Dihli (Delhi), the capital city of the sultan. But when the news officers called "informants" write a letter from Sint region, it reaches the sultan within five days thanks to the private mail system!" (Aykut, 2018, s.584, C.2)

The Category-Code and Contents of the Seventh Grade "(7.2.1.) Explains the Process of Emergence of the Ottoman Empire as a Political Power and the Factors Affecting This Process" are given in Figure 3.

Figure 3: Category-Code and Contents Related to Social Studies 7.2.1 Gains

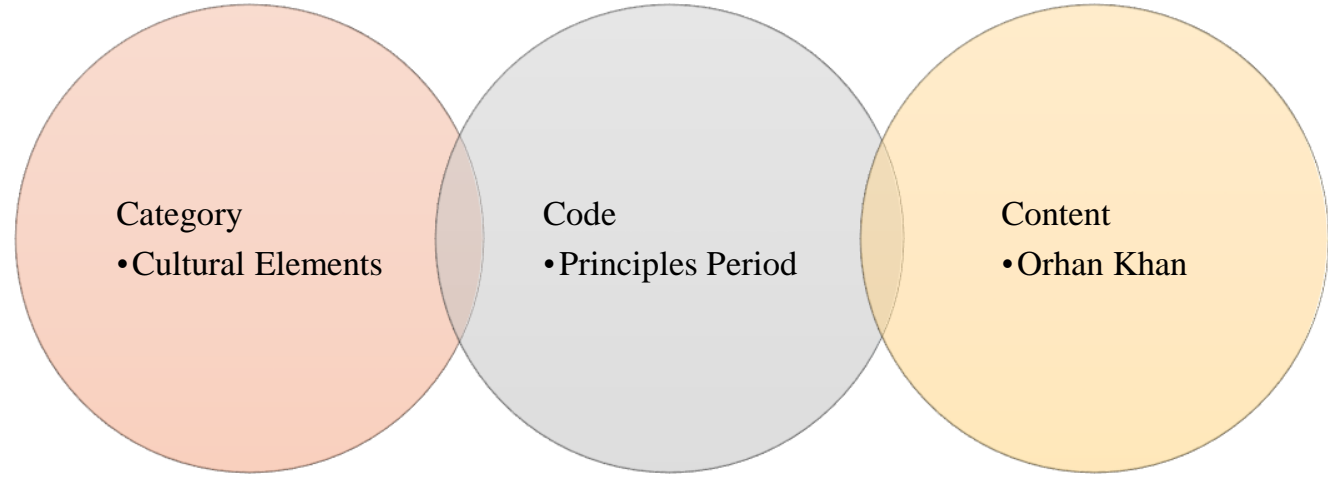

In Figure 3, direct quotations regarding the "Orhan Khan" content related to the "Principles Period" code in the "Cultural Elements" category related to the 7.2.1 gains obtained in the Travel Book of Ibn Battuta are as follows:

"The sultan of Bursa is Ihtiyaruddin Urhan Bek (Orhan Bey). Urhan is the son of Sultan Osmanjuk. "Cûk" means small in Turkish. This sultan is the greatest of the Turkmen rulers in terms of property, country and military. His forts are close to a hundred. He spends most of his time wandering around. Staying in each castle for a while, he tries to look around and make up for the deficiencies. It is said that he does not stay in any city for more than a month, he constantly fights with the infidels and besieges them! His father has already taken Bursa from the hands of the Greeks, and his grave is next to the city mosque. This used to be a Christian church. According to what is told, father Osmanjuk besieged the city of Yeznik (Iznik) for twenty years and died before conquering it. Then his son continued to besiege and conquered twelve years later." (Aykut, 2018, p.430, C.1)

The Category-Code and Contents of the Seventh Grade (7.3.1.) Learning Outcomes Make Inferences About the Factors Affecting Settlement From Past to Present Through Case Studies are given in Figure 4. 
Figure 4: Category-Code and Contents Related to Social Studies 7.3.1 Gains

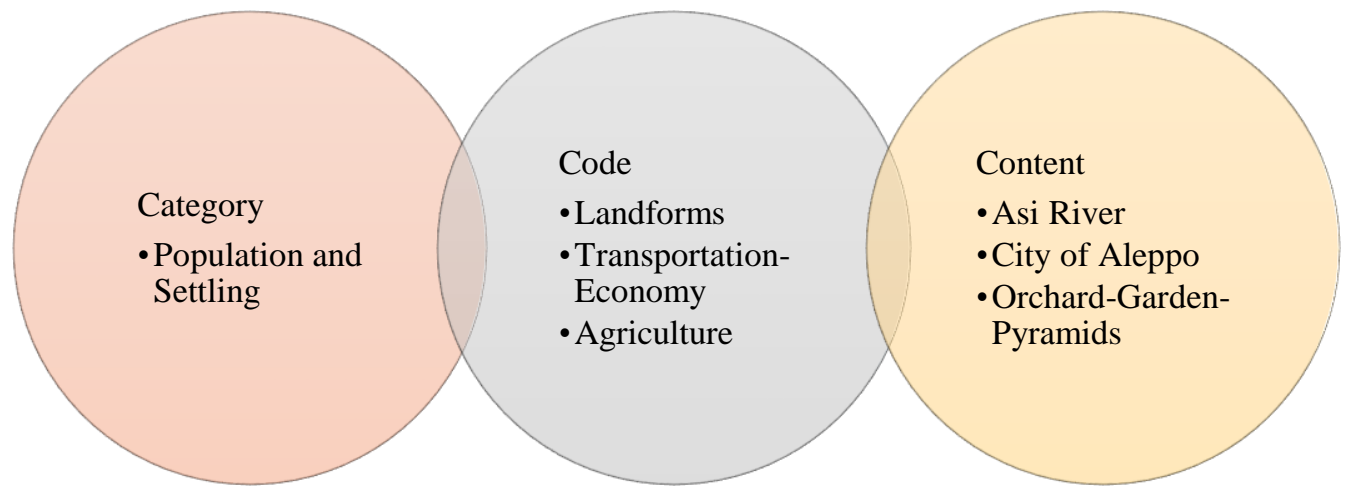

In Figure 4, the content of the "Asi River" related to the "Landforms" code in the "Population and Settlement" category associated with the achievement 7.3.1 obtained in the Travel Book of Ibn Battuta; "City of Aleppo" content related to "TransportationEconomy" code; Direct quotations from the content of "Orchard-Garden-Pyramids" related to the "Agriculture" code are as follows:

"Hama (Syria) ...The water closets are quite big, like the heavens. The great river called the asi passes through here. It has an outer neighborhood called Mansuriye. Located at the entrance of the city, this neighborhood is bigger than the main city. There are busy bazaars and regular baths here." (Aykut, 2018, p.101, C.1)

"Aleppo has a unique advantage in terms of its location. Its streets are wide and orderly. Since the bazaars are covered with wooden roofs, passers-by and shopkeepers feel comfortable." (Aykut, 2018, p.107, C.1)

"We set off from the Jebel-i Lebanon region to the city of Baalbek. This is a very old city. It is one of the most pleasant towns in the Syrian region. It is surrounded by very fertile and beautiful gardens. Its land is fed by rivers. It is similar to Damascus with its successive charitable works and gardens that delight the eyes." (Aykut, 2018, p.124, C.1)

The Category-Code and Contents of the Seventh Grade (7.3.2) Interpretations of Turkey's Demographic Characteristics Based on the Factors Affecting the Distribution of the Population in Turkey are given in Figure 5: 
Figure 5: Category-Code and Contents Related to Social Studies 7.3.2 Gains

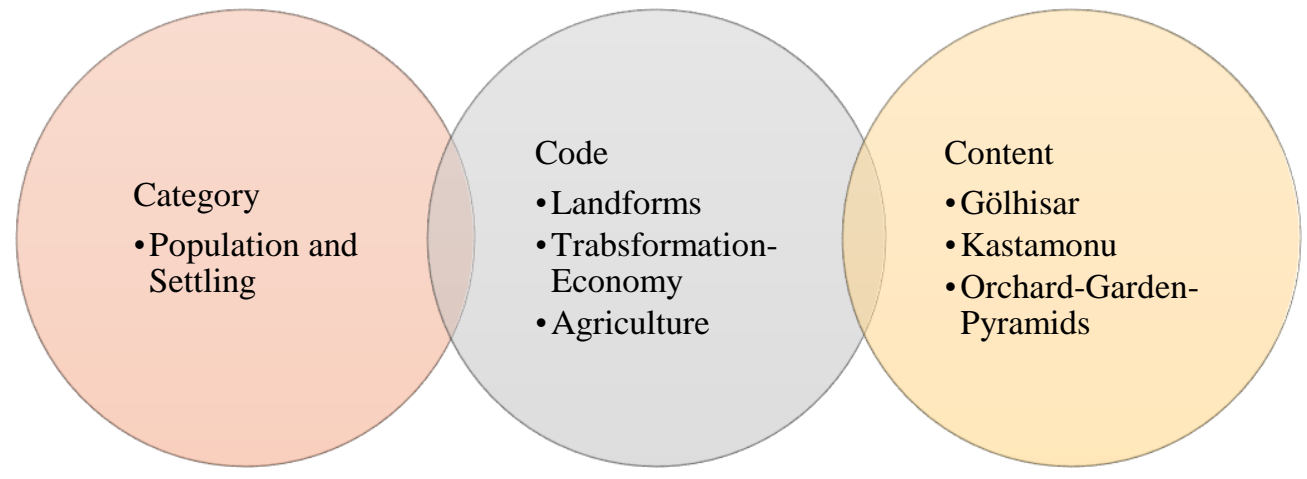

In Figure 5, direct quotations from the "Golhisar" content related to the "Landforms" code in the "Population and Settlement" category associated with the 7.3.2 achievement obtained in Ibn Batuta's Travel Book; "Kastamonu" content related to the "Transportation-Economy" code; the content of "Orchard-Garden-Pyramids" related to the "Agriculture" code are as follows:

"We headed for Kulhisar (Gölhisar). This is a small town surrounded by water on all four sides. There are plenty of reeds in the lake. There is only one road to town; It stretches between the reed and the waters. A gorge like a bridge that only a horseman can cross! The town is built on a hill rising in the middle of the water; it looks like a strong castle that is difficult to capture." (Aykut, 2018, p.407, C.1)

"The next day, I went to Kastamunya (Kastamonu), this city is one of the most beautiful and well-kept towns of Anatolia. There is every convenience for living! Goods prices are very cheap." (Aykut, 2018, p.439, C.1)

"From there, we moved to Sabartâ (Isparta). This is a prosperous city too, with rich bazaars. Tea is flowing all around. It is a town with plenty of vineyards. The city castle is on a high hill. We got there in the evening. We were guests at the local judge's house." (Aykut, 2018, p.406, C.1)

"From there we were sent to Ekrîdur (Egirdir). It's a crowded city. The bazaars are cute and rich. The area around the city is wooded. Gardens are all around...". (Aykut, 2018, p.406, C.1)

The Category-Code and Contents of the Seventh Grade (7.4.1) Examines Change and Continuity in the Protection, Dissemination and Transfer of Information Achievement are given in Figure 6: 
Figure 6: Category-Code and Contents Related to Social Studies 7.4.1 Gains

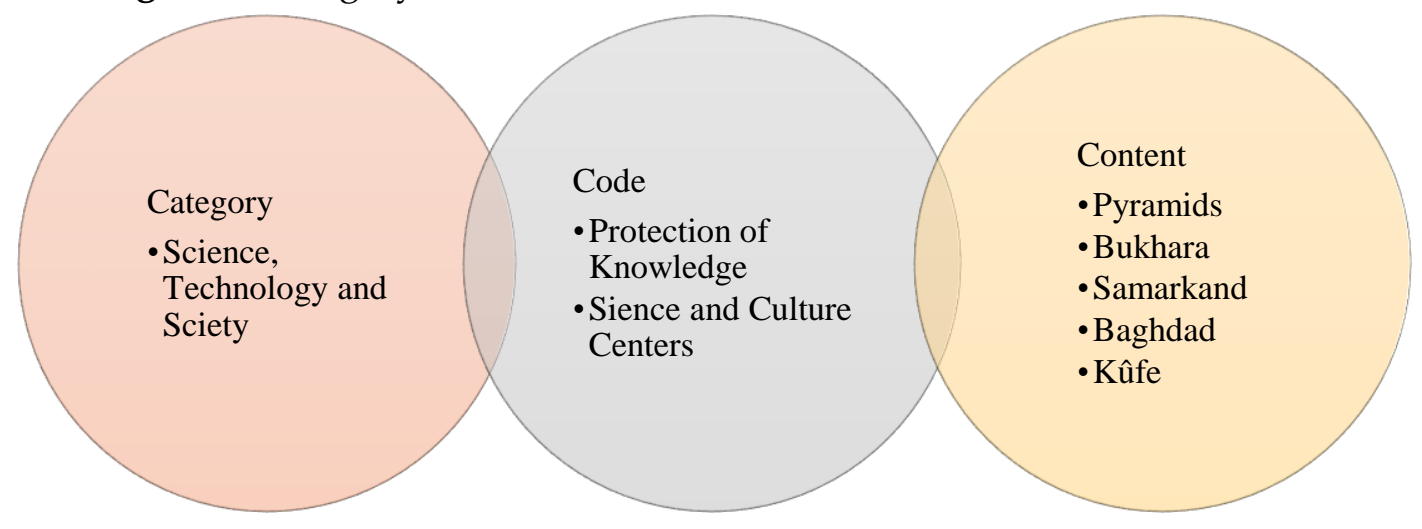

In Figure 6, the content of "Ehrams (pyramid)" related to the "Protection of Information" code in the "Science, Technology and Society" category associated with the 7.4.1 achievement obtained in the Travel Book of Ibn Battuta; Direct quotations from the content of "Bukhara, Samarkand, Baghdad, Kufe" related to the "Science and Culture Centers" code are as follows:

"Fearing the loss of science and art, it is Hermes again who built ehrams and temples for the first time and depicted all art and science instruments so that they would remain on their walls forever, and even embroidered scientific information in special articles." (Aykut, 2018, p.52, C.1)

"Travel to Desolate Bukhara: We traveled one more day through successive vineyards, gardens, houses and fields; Finally, we reached the city of Bukhara, the hometown of Abu Abdullah Muhammet Ismail Bukhari, the leader of hadith scholars. This city was once the center of the Maverâunnehr-i Ceyhun region (cities beyond the Ceyhun river) and was destroyed by the infamous Tatar origin Tinkiz (Chingiz), who is the ancestor of the Iraqi rulers (Ilkhanids). Its mosques, madrasas and bazaars are in ruins. Very few of them are intact. Its people are miserable! Their testimonies are not accepted in Huvarezm and other regions! Because they are notorious for their negative qualities such as tribalism, denial of right and defense of wrong. There is no one who knows a little bit of science,values knowledge today!" (Aykut, 2018, p.527, C.1)

"There are large mansions and pavilions on the banks of the river in Samarkand that show how hardworking and ambitious the people of the city were once. Much of it is now in ruins... So is most of the city. This city has neither walls nor gates! The interiors have gardens only. Samarkands are good-natured people; They approach the stranger with compassion and love. They are better than the people of Bukhara!" (Aykut, 2018, p.541, C.1).

"Baghdad, this is a very old city. It was the capital city of the Abbasid caliphate and the center of invitation of Quraysh-origin imams. But everything they built was destroyed, 
only the name remained. It can be said that there is no trace of the savages of the time before they extended their bloody swords there." (Aykut, 2018, p.316, C.1)

"Kufa, one of the main cities of the land of Iraq, is the home of the friends of the Prophet, the great scholars and the virtuous, and the believers. It is a privileged place because it is the center of Ali's caliphate. However, because the enemy's hand extended to this place and the Bedouins from the Hafâce tribe committed banditry, all parts of it were devastated." (Aykut, 2018, p.311, C.1)

The Category-Code and Contents of the Seventh Grade (7.4.2.) Learners Growing in Turkish-Islamic Civilization Discuss Their Contributions to the Scientific Development Process are given in Figure 7:

Figure 7: Category-Code and Contents Related to Social Studies 7.4.2 Gains

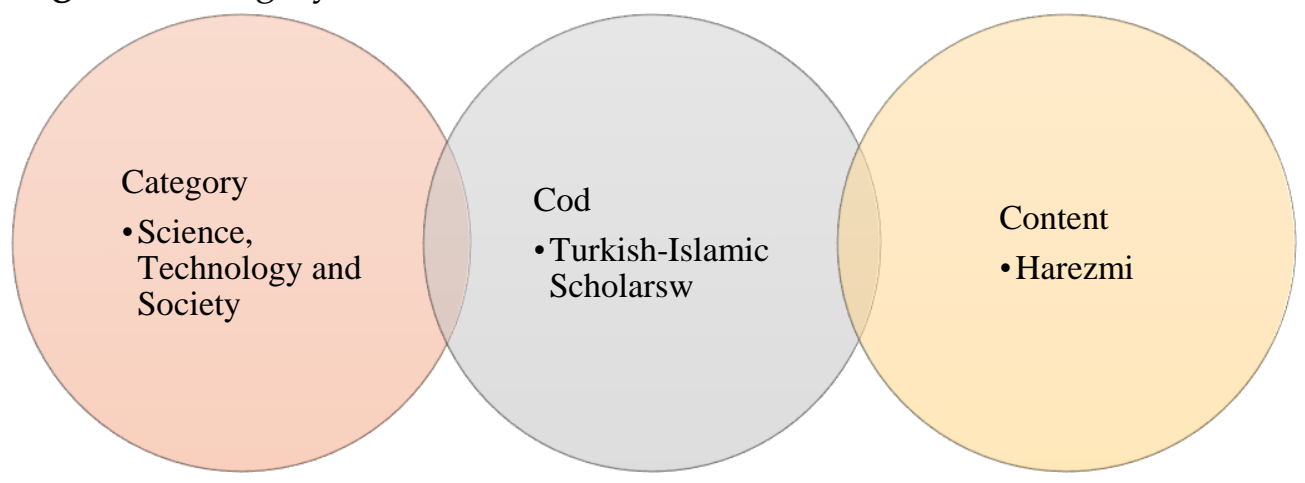

In Figure 7, direct quotations from the "Khorezmi" content related to the "TurkishIslamic Scholars" code in the "Science, Technology and Society" category associated with the 7.4.2 achievement obtained in Ibn Batuta's Travel Book are as follows:

"The Sultan of Milas is Menteşeoğlu Şucaeddin Urhan Bek. Among the rulers, he was known for his stature, clean morals and intelligence. He usually stays together with scholars and gives them great value. He always has a group of figh scholars with him. Fakih Huvârezmî (Khwarizmi), a virtuous person who is an expert in various sciences, is one of them. When I met him, the sultan was offended by him; For going to Ayasluk, meeting with the ruler of that region and accepting the gift he gave. That's why he went to Ayasluk, met with the ruler of that region and accepted the gift he gave. That's why Huvarezmi asked me to tell him about my situation while meeting with the Milas bey. I have expressed my personal opinion about his virtue and sound knowledge. Indeed, the sovereign's doubts about Huvarezmi have vanished!" (Aykut, 2018, p.411-412, C.1)

The Category-Code and Contents of the Seventh Grade (7.5.3) Gives Examples of the Works of Institutions and Non-Governmental Organizations and Their Roles in Social Life are given in Figure 8: 
Figure 8: Category-Code and Contents Related to Social Studies 7.5.3 Gains

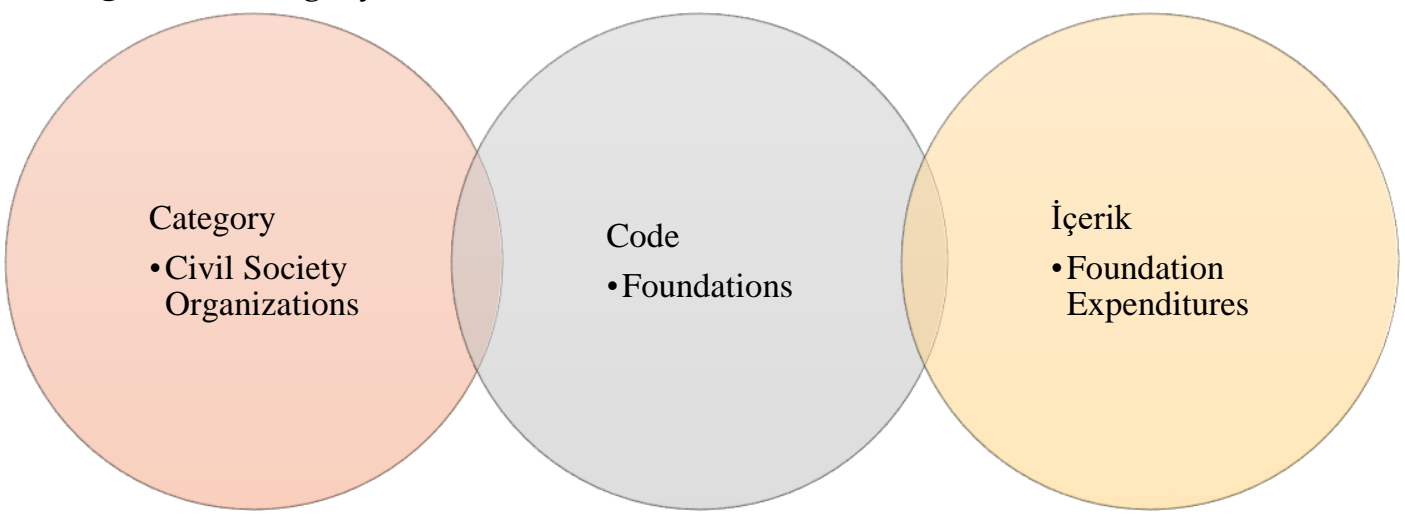

In Figure 8, direct quotations regarding the "Foundation Expenditures" content related to the "Foundations" code in the "Civil Society Organizations" category associated with the 7.5.3 achievement obtained in the Travel Book of Ibn Batuta are as follows:

"Rabve has many foundations consisting of fields, vineyards, gardens and residential areas. Salaries of imams and muezzins, expenses of passengers and needs of strangers are met from these foundations" (Aykut, 2018, p.150, C.1).

The Category-Code and Contents of the Seventh Grade (7.5.4) Recognition of Institutions Playing a Role in Vocational Education and Professional Ethics in Turks throughout History are given in Figure 9:

Figure 9: Category-Code and Contents Related to Social Studies 7.5.4 Gains

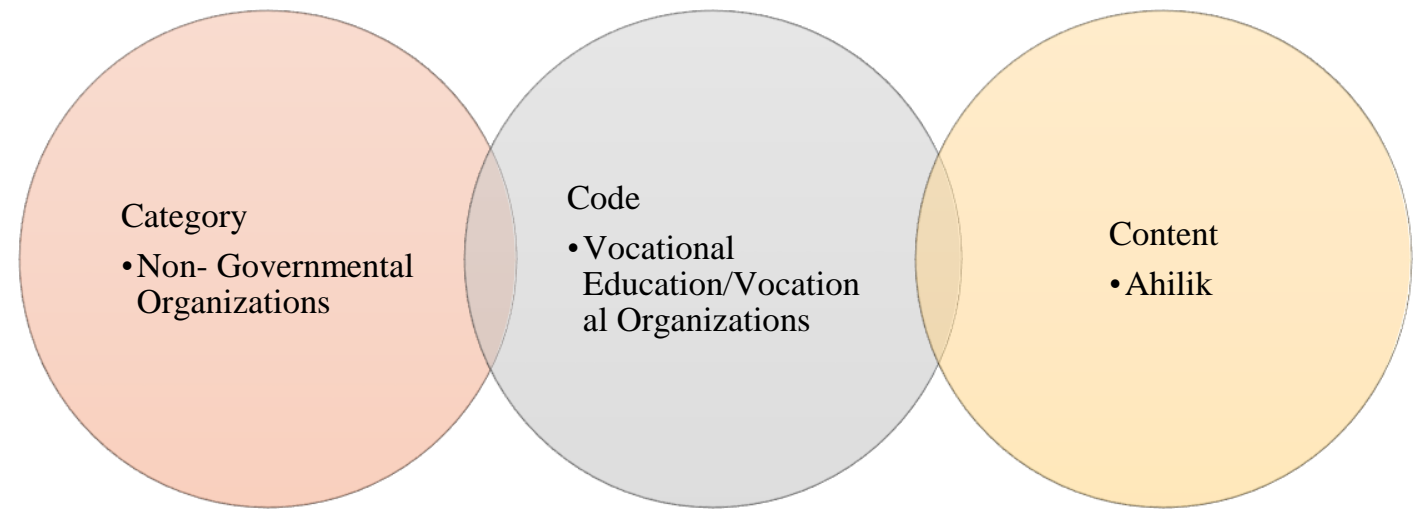

In Figure 9, direct quotations regarding the "Ahilik" content related to the "Vocational Education/Vocational Organizations" code in the "Non-Governmental Organizations" category associated with the 7.5.4 achievement obtained in Ibn Batuta's Travel Book are as follows:

"When we arrived at the lodge, we found the furnaces burning. We took off our clothes immediately and were left with a single layer of clothing; We warmed up in front of the fire. Brother immediately brought the bark of various foods and fruits. May Allah give the 
best reward to these dervishes, who show compassion and mercy to strangers, who do not spare their help to those who come and go, who embrace them, and who welcome their guests as if they were their own relatives! We spent that night in peace; we are at ease, our body is calm..." (Aykut, 2018, p.437, C.1)

The Category-Code and Contents of the Seventh Grade (7.7.3.) Questioning Stereotypes About Various Cultures Gain are given in Figure 10:

Figure 10: Category-Code and Contents Related to Social Studies 7.7.3 Gains

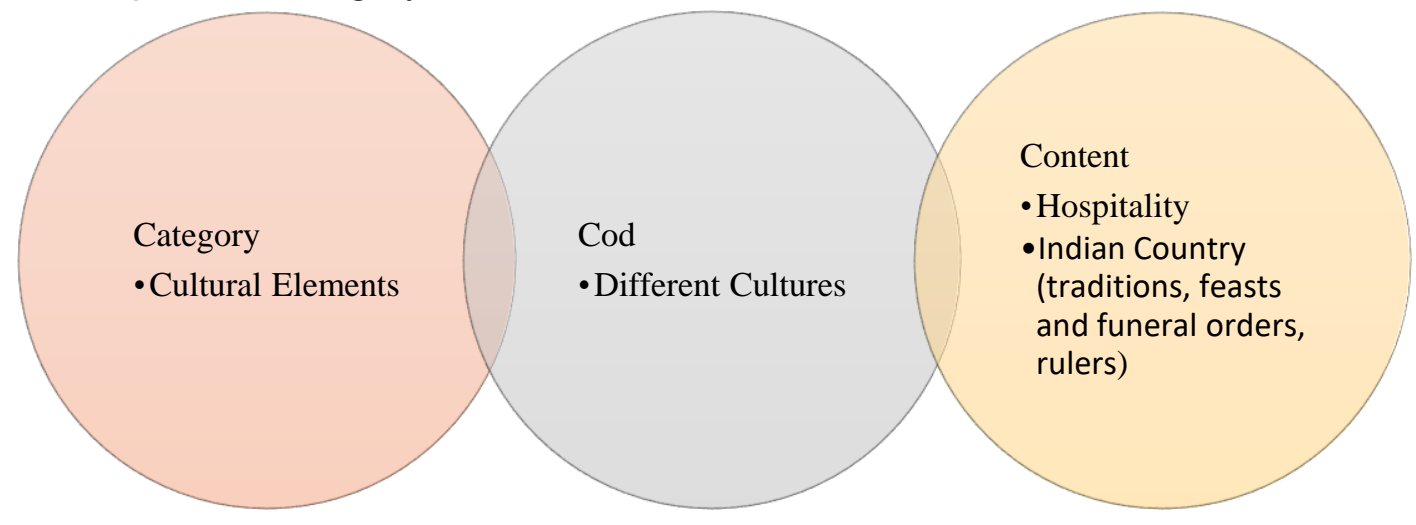

In Figure 10, the content of "Hospitality, Indian Country (traditions, feasts and funeral orders, rulers)" related to the "Different Cultures" code in the "Cultural Elements" category associated with the 7.7.3 achievement obtained in the Travel Book of Ibn Battuta. The relevant direct quotes are as follows:

"The people of Basra are good-natured. They show closeness to the stranger, they do not violate their rights. No foreigner who comes here does not feel expatriate and lonely, and he is not afraid because he was left alone." (Aykut, 2018, p.265, C.1)

"The attitude of the Indian ruler towards guests and foreigners: Abu'l-Mujahid Muhammad Shah, the Indian ruler, gives generous treats to foreigners as it is a custom. He does not fail to respect them. He even brings them to governorships and positions. That is why their private men, viziers, judges, chamberlains and brothers are mostly foreigners. He even issued an edict stating that foreigners serving in his government should be called "Eizze" (saints, venerable ones)." (Aykut, 2018, p.585, C.2)

\section{Discussion}

Ibn Batuta's Seyahatname was published by A. Sait Aykut in 2018 in 2 volumes and 60 chapters. In addition to visiting many countries on three continents, meeting with important people of the period; In the geographies he traveled to, he included important information about agriculture, transportation, economy and sociological structure in the region. In particular, the sociological description of the Anatolian geography is important 
in terms of establishing a connection between the past and the present. There are many findings that can help students to understand change and continuity such as agriculture and geographical factors affecting the settlement related to the gains of "Makes Inferences About the Factors Affecting the Settlement from Past to Present Through Case Studies". Examining the Gain Gives Examples to the Works of Institutions and Non-Governmental Organizations and Their Roles in Social Life, many findings that will set an example regarding the importance and historical development of foundations and associations were found. As a result of the findings, it can be shown among the resources that social studies teachers, students and teacher candidates can benefit from.

Ata (2013) stated in his research that travel books should be given more space in social studies textbooks; not being limited to just this, it emphasizes the necessity of enabling students to look critically by doing activities with various pictures. In this direction, it can be said that it is compatible with the findings in Ibn Batuta's Travel Book in terms of giving information about different geographies. Again, Çelik (2016) emphasized that Evliya Çelebi's Travel Book, which he examined in line with the achievements in the Social Studies curriculum, in his research, emphasized that academic research could be done in the social studies lesson and could be supported by various projects in the social field. Yakar (2013) emphasized in his research that the use of travel books in social studies teaching is one of the important materials in terms of empathy and perceiving change. In this direction, it can be said that the results of our research are compatible with the results of the studies conducted. Again, Oruç and Aygün (2018) reached the findings about the travel books in the social studies textbooks in their research. In line with the findings, they emphasized that more travel books should be included in social studies textbooks.

Kaya and Ekici (2015), as a result of their research titled "Using travel writings in Social Studies teaching: Gülten Dayığlu's travel writings", emphasized that it can contribute to the gains of skills such as empathy skills, critical thinking, questioning, problem identification and analysis. Again, Baştuğ (2019) examined the works of domestic and foreign travelers who came to Nevşehir and associated them with the achievements in the Culture and Heritage learning area. In the works, findings about the region in terms of physical, cultural, socio-economic, demographic and information are included. As a result of his research, Çelik (2019) emphasized that social studies teacher candidates can design activities by associating extracurricular activities and literary genres, and that various activities related to travel writings can be included in the curriculum.

- Map studies related to the Ibn Batuta Travel Book route can be carried out.

- The historical figures in Ibn Batuta's Travel Book can be animated with dramatization, role-playing methods and techniques.

- On the value and importance given to Turkish women, story creation studies can be done in line with the findings in the work.

- Experimental studies can be done to compare the factors affecting the settlement in the past and the factors affecting the settlement today. 
- Social studies teacher candidates can be trained on how to use travel books.

- Stories suitable for the development level of students can be created from the sections selected from Ibn Batuta's Travel Book.

\title{
Conflict of Interest Statement
}

The authors declare no conflicts of interests.

\begin{abstract}
About the Author(s)
Zeynep Öncü has a master's degree from Afyon Kocatepe University and her area of interest is Social Studies education.

Dr. Nusret Koca is a Professor at Afyon Kocatepe University, Faculty of Education, Department of Basic Education.
\end{abstract}

Dr. Mehmet Tamer Kaya works at Afyon Kocatepe University, Faculty of Education, Department of Social Studies Education. His areas of specialization include Social Studies Education.

\section{References}

Ata, B. (2013). Sosyal bilgiler öğretim programı ve seyahatnameler: "Çocuklar, ninelerimiz ve dedelerimiz çok yardımseverdi." Türk Yurdu, 33(310), 164-166.

Asiltürk, B. (2009). Edebiyatın kaynağı olarak seyahatnameler. International Periodical for the Languages, Literatur and History of Turkish or Turkic, 4(1), 912-995.

Aykut, A. S. (2018). İbn battûta seyahatnamesi (5. Bask1). İstanbul: Yap1 Kredi Yayınları.

Baştuğ, H. (2019). Sosyal bilgilerde seyahatnamelerin yeri ve seyyahlarn gözüyle nevşehir. (Yayımlanmamış Yüksek Lisans Tezi). Necmettin Erbakan Üniversitesi Eğitim Bilimleri Enstitüsü, Konya.

Bilgin, N. (2017). Sosyal bilimlerde içerik analizi teknikler ve örnek çalışmalar. Ankara: Siyasal Kitapevi.

Çelik, A. (2019). Gezi yönteminin sosyal bilgiler öğretmen adaylarının akademik başarılarına etkisinin ve gezi yazısı yazma deneyimlerine ilişkin görüşlerinin incelenmesi. Kırşehir Ĕ̆̈itim Fakültesi Dergisi, 20(1), 395-413.

Çelik, A. (2016). Sosyal bilgiler dersi öğretiminde evliya çelebi seyahatnamesinin kullanımı. (Yayımlanmamış Doktora Tezi). Gazi Üniversitesi Eğitim Bilimleri Enstitüsü, Ankara.

Çevik, M. (2015). İbn battuta seyahatnamesi:(Tuhfetu'n-nuzzâr fi garâibi'l-emsâr ve acâibi'lesfâr). İstanbul: Bilge Kültür Sanat.

Demir, O. Ö., (2017). Nitel araştırma yöntemleri. İçinde; Sosyal bilimlerde araştırma yöntemleri (Ed: K. Böke), ss. 287-316. İstanbul: Alfa Yayıncılık.

Dündar, Z. \& Baysan. S. (2017). Sosyal Bilgiler Öğretiminde Efsanelerin Kullanımı. International Periodical for the Languages. Literature and History of Turkish or Turkic. 12(18), 293-310. 
Kaya, E. \& Ekici, M. (2015). Sosyal bilgiler öğretiminde gezi yazılarından yararlanma: Gülten dayığlu'nun gezi yazıları örneği. Türkiye Sosyal Araştırmalar Dergisi, 1(1), 87-114.

MEB. (2018). Sosyal bilgiler dersi öğretim programı (ilkokul ve ortaokul 4, 5, 6 ve 7.sınıflar). Ankara: Millî Eğitim Bakanlığı Yayınları.

Maden, S. (2008). Türk edebiyatında seyahatnameler ve gezi yazıları. A. Ü. Türkiyat Araştırmaları Enstitüsü Dergisi, 37, 147-158.

Oruç, Ş. ve Aygün, M. (2018). Sosyal bilgiler ders kitaplarında seyahatnameler. Uluslararası Ders Kitapları ve Eğitim Materyalleri Dergisi, 1 (1), 46-57.

Öztürk, C., Otluoğlu, R. \& Coşkun, K., S. (2014). Sosyal bilgiler öğretiminde edebi ürün ve yazılı materyaller (6. Bask1). Ankara: Pegem Akademi.

Öztürk, C. \& Otluoğlu, R. (2002). Sosyal bilgiler öğretiminde yazılı edebiyat ürünlerini ders aracı olarak kullanmanın duyuşsal davranış özelliklerini kazanmaya etkisi. Atatürk Ĕ̈itim Fakültesi Ĕ̆itim Bilimleri Dergisi, 15, 173-182.

Tavşancıl, E. \& Aslan, A. E. (2001). Sözel ve yazılı materyaller için içerik analizi ve uygulama örnekleri. Ankara: Epsilon Yayınları.

Türk Dil Kurumu, (2019). Seyahatname tanımı, https://sozluk.gov.tr/ (Erişim Tarihi: 29.03. 2019).

Yıldırım, A. \& Şimşek, H. (2016). Sosyal bilimlerde nitel araştırma yöntemleri (10. Baskı). Ankara: Seçkin Yayıncılık.

Yazıc1, H. (2009). Seyahatname. Diyanet İslam Ansiklopedisi, (37), 13-16.

Yakar, H. (2013). Cumhuriyetten günümüze uygulanmış olan ilköğretim sosyal bilgiler öğretim programlarında seyahatnamelerin incelenmesi. (Yayımlanmamış Yüksek Lisans Tezi). İnönü Üniversitesi Eğitim Bilimleri Enstitüsü, Malatya. 
Creative Commons licensing terms

Author(s) will retain the copyright of their published articles agreeing that a Creative Commons Attribution 4.0 International License (CC BY 4.0) terms will be applied to their work. Under the terms of this license, no permission is required from the author(s) or publisher for members of the community to copy, distribute, transmit or adapt the article content, providing a proper, prominent and unambiguous attribution to the authors in a manner that makes clear that the materials are being reused under permission of a Creative Commons License. Views, opinions and conclusions expressed in this research article are views, opinions and conclusions of the author(s). Open Access Publishing Group and European Journal of Education Studies shall not be responsible or answerable for any loss, damage or liability caused in relation to/arising out of conflicts of interest, copyright violations and inappropriate or inaccurate use of any kind content related or integrated into the research work. All the published works are meeting the Open Access Publishing requirements and can be freely accessed, shared, modified, distributed and used in educational, commercial and non-commercial purposes under a Creative Commons Attribution 4.0 International License (CC BY 4.0). 